\title{
ALICANTE BEACH- CITY SUSTAINABLE DEVELOPMENT
}

\author{
J. GARCÍA-BARBA, L. ARAGONÉS, I. LÓPEZ, M. LÓPEZ, A. TENZA \& J.I. PAGÁN \\ Department of Civil Engineering, Alicante University, Spain.
}

\begin{abstract}
Our research is focused on the city of Alicante (Spain). In concrete, the sunken area studied is placed at the south of Alicante Port, being the point of entry from the airport to the city. There are two important reasons that have generated that depressed area. Firstly, the development of the city has led to a change in the use of the soil, and secondly, the extension of Alicante Port. This area used to be a metallurgical industrial zone, but during the last 40 years, it has overcome an urban growth. The European Office for Harmonization in the Internal Market (OHIM), the most modern Film Studio in Europe 'Ciudad de la luz', a desalination plant and residential complexes and offices have settled down there. Unfortunately, all this development has occurred without taking into account the coastal needs. Regarding to that, several elements that contribute to the deterioration of the area can be found along the coast, that is the mouth of a rift called 'Barranco de las Ovejas' at north, the 'Agua Amarga' rift at south and the desalination sewage pipe. Besides, there is a merchandise train line adjoining the Maritime-Terrestrial Public Domain that provides service to the port, but hinders the way for pedestrians going to the beach. Keywords: coast, industrial activities, railway, sustainable development.
\end{abstract}

\section{INTRODUCTION}

Society is continually changing; this is a characteristic of the present century. Not only changes our local reality, but also the global reality. World population and its demographic movements, migrations and jobs, are responsible for the change and renovation in the cities. The city of Alicante has been an example of renovation of its productive sector.

Throughout the twentieth century the city developed into the suburbs. It used the existing roads, resulting in a number of suburban areas without minimum services.

These areas were opened to the periphery generating a provision fan that started the radial pattern, in which the city grew in successive periods.

The district of Textile Industries and San Gabriel was developed to the south [1].

The aluminium industry was in charge of the largest urban development in the neighbourhood of San Gabriel.

However, in the seventies and eighties the traditional industrial sector was affected by the oil crisis, the Spanish political situation and the entry into international markets by producers from Southeast Asia, among other problems. These issues caused the industry was disappearing, becoming the south of Alicante in a degraded industrial complex.

Urban development and tourism were focused towards the north of the city [2].

The occupation of the coast to the south was developed very differently in the north area. It is characterized by a discontinuous occupation along the National Highway N-332, based on the development of large isolated urban developments (Urbanova, Arenales del Sol and Gran Alacant), consolidating a highly fragmented pattern of land occupation [2]. 
The area has increasingly become important, resulting in the creation of a new centre for the implementation of certain administrative or service activities, located away from the town of Alicante. Office location for the registration of trademarks and designs European Union (OAMI), and the Ciudad de la Luz, the cinema studios powered by the Generalitat Valenciana, on the south coast. These are cases in which a decentralization of service activities within an urban area has been carried out. A new administrative, tertiary and residential activity has been settled, with housing construction promoted by the Valencian Institute of Housing.

This is also an area that as well as being remote and isolated from urban centre does not have excessive easy access to highways crossing the Alicante area. The relationship of this area with the road network occurs through the national road between Elche, Alicante and the airport. However, the proximity of the airport to this enclave has become a strong hotel growth area (three hotels are located in a very small area) [2].

Although a number of activities that allow more complex applications in this area have already been established, the fragmentation of the land uses and the existence of spaces for the implementation of new activities allow the further restructuring of the whole territory. In this sense, the existence of the airport, the areas of tertiary and administrative activity and the chances of the transformation of some industrial sites, together with the expected residential growth in this area, make this area one of the current major challenges to consider.

The potential tourism that the city of Alicante can generate is one of the most important aspects, Cities like Bilbao, an industrial municipality, had the necessity to be transformed radically after the industrial decline. The city returned to be important and was located in the national and international stages. This change was articulated through sustainable urban planning that gave a new physiognomy and identity to the city [3], thus making it a must-see for tourists who choose each year to visit the Basque Country in particular and Spain in general.

The aim of this work will be made an urban and sustainable development in the southern coastal area of the city of Alicante. This area is in a high state of degradation by human activities carried out in the past. Giving ground continuity to the promenade may well encourage the citizens and tourists from Alicante to walk and enjoy the views of the sea and the temperate climate. It is intended not only to continue the promenade but also to regenerate and generate beaches around the stretch studied so that three objectives are achieved: (i) protection of the coastline, (ii) improving recreational activities in this new space and (iii) improvement in economic activity in the area.

\section{STUDY AREA}

This study is located at the south of the city of Alicante, extending from the San Gabriel neighbourhood to the junction of national roads N-332 and N-340. It has a length of $3 \mathrm{~km}$ (Fig. 1).

\section{PROBLEMS}

The southern coast of Alicante is the lowest urban density area, but with the greatest potential for sustainable urban development. At the north is located the San Gabriel neighbourhood and at the south the 'Urbanova' block-height buildings. These residential areas are inhabited mostly in summer, and they have few leisure activities.

Also note that despite the proximity to the Alicante Airport - located in El Altet - there have been almost no interventions in the area, unlike the north of Alicante, where there has 


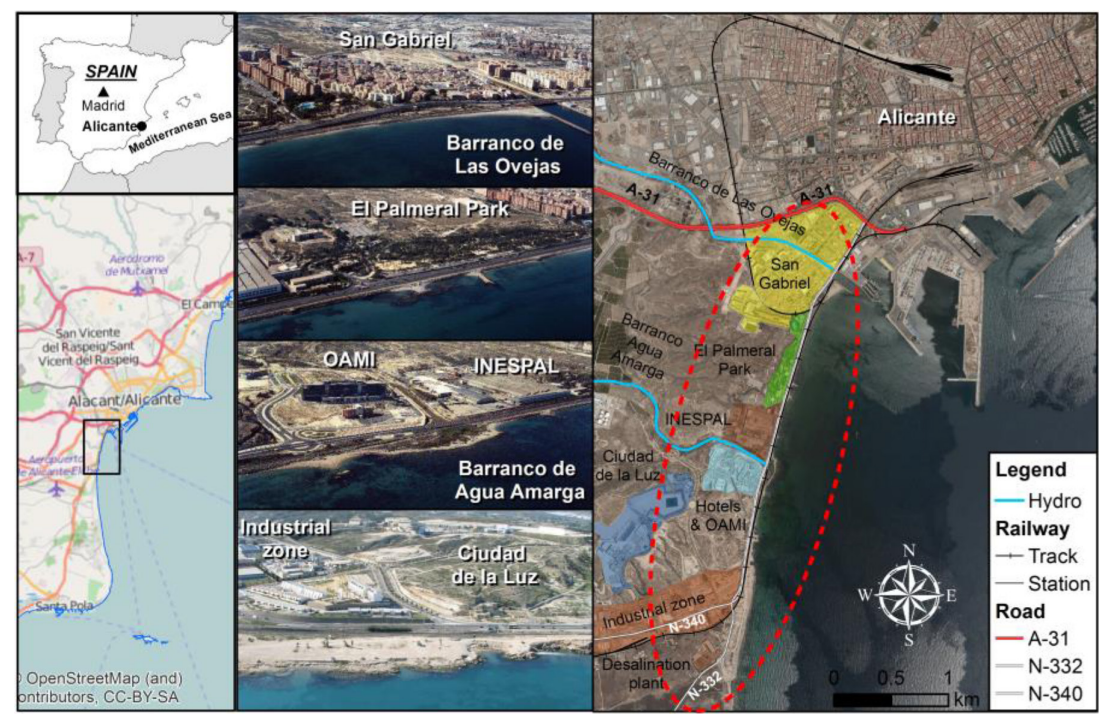

Figure 1: Study area.

been the urban development of the city. However, nowadays it is one of the sectors of the municipality in which the prospects for development and economic revitalization are more obvious, because its area of influence has the presence of OIMA (Office for the registration of trademarks, drawings and models of the European Union), the audio-visual complex Ciudad de la Luz film school and the British School of Alicante.

Within this complex scenario also there is an area of high landscape value, as the park of El Palmeral is. It is located at the southern exit of Alicante, facing the sea, with hundreds of palm trees between walks, water areas and waterfalls.

Thus, the presence of these complexes isolated from the waterfront, together with the fact that being the presumably welcome to the city, make it convenient to take the requalification of the coastal scene by the lack of urban spaces and equipment that leading to its use, specifically, compared to the park of El Palmeral and the San Gabriel neighbourhood. Currently it has a deplorable state and complete abandonment, with the only presence of the railway Valencia-Cartagena. This railway line is a barrier between the people and the coastal zone, thereby preventing progress between the land area and coastline, developing a city back to the coast (Fig. 2).

Therefore, there is a zone without coastal accessibility during the $3 \mathrm{~km}$ long coast, because it does not have any access to it, thus leading to a trouble spot. Still, the coastal strip is frequented by swimmers and fishermen, which has led in recent years a large number of accidents, being very remarkable there is not level crossing barrier linking the San Gabriel neighbourhood to Torrellano (6 killed in the last 10 years) [4-6].

\section{SOLUTIONS}

There is a necessity to promote the area, a traffic management as well as provide a new ride coastal maritime thereby improving mobility in the region and connecting the entire coastal front south of Alicante. 


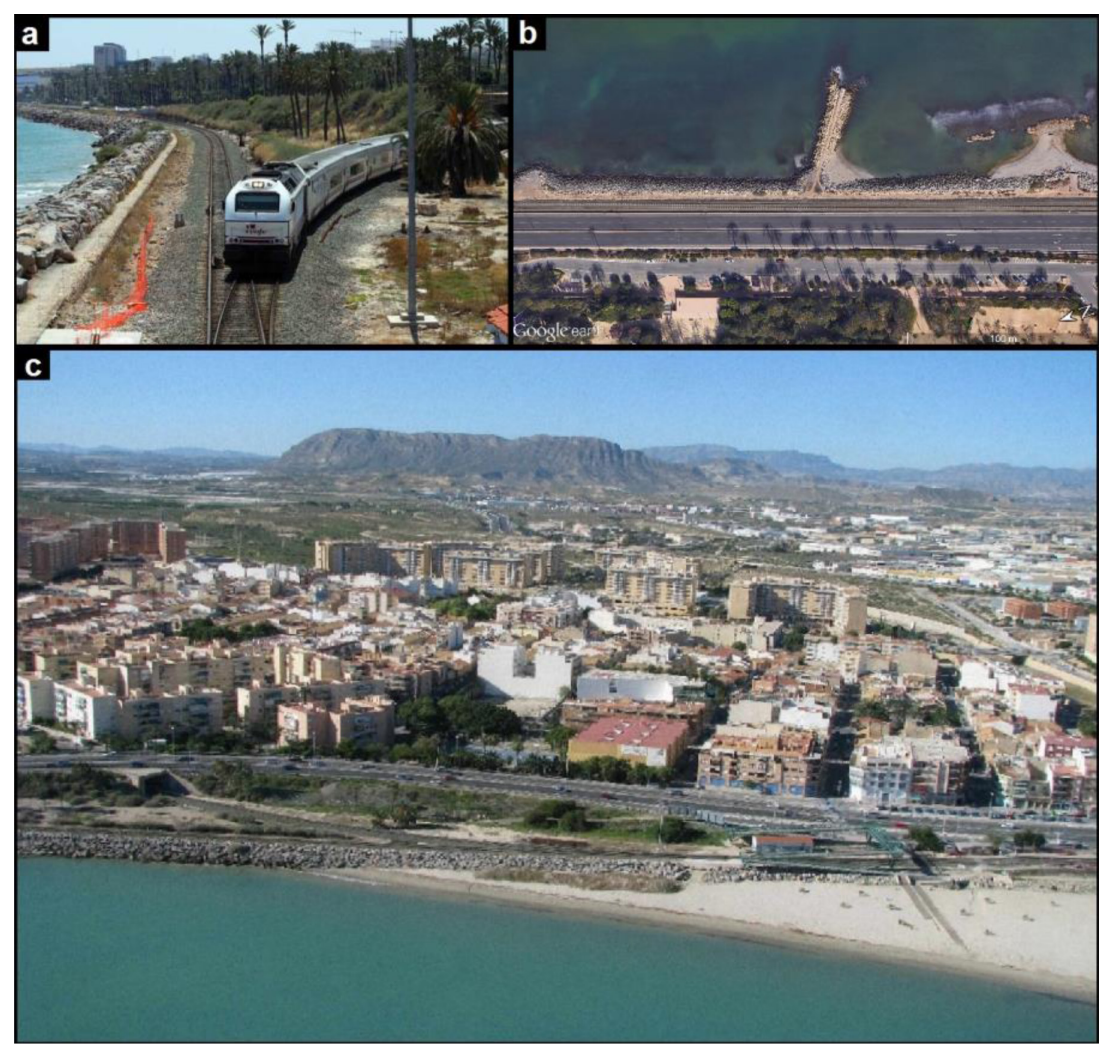

Figure 2: (a) Reversal railway (b) View national road, railway and Palmeral Park (c) View San Gabriel national road and railway.

The solution adopted for the design of the promenade has been developed to maintain the same structure of the surrounding areas of Alicante. A bike path was included, which is linearly along the promenade and all the way to the beach (Fig. 3).

Access by road traffic is limited to two areas, one located in the San Gabriel neighbourhood and another to the south after the Barranco of Agua Amarga. Only in these areas, parking surfaces are generated, to thereby serve all new users visiting the area as a result of the rehabilitation. The width of the area of walk for users is $6 \mathrm{~m}$ (excluding green areas, parking...), parks and recreation areas will also be generated (Fig. 4). Small viewpoints will be created along the promenade. The main cross-section is two medium gardens of 3 meters wide each, a bike path of 3 meters and an area of pedestrian traffic of 6 meters. The total section is 15 meters (Fig. 5). In areas of parking section is considerably increased. Thus, the pedestrianisation of the area is achieved, which is currently lacking and will be a very attractive space for pedestrians.

In order to carry out this action it is necessary to suppress the railroad that passes through this area. One of the proposed solutions is to divert the route inward as was reflected in the previous General Plan of the City of Alicante, making it go through the Alicante airport. 


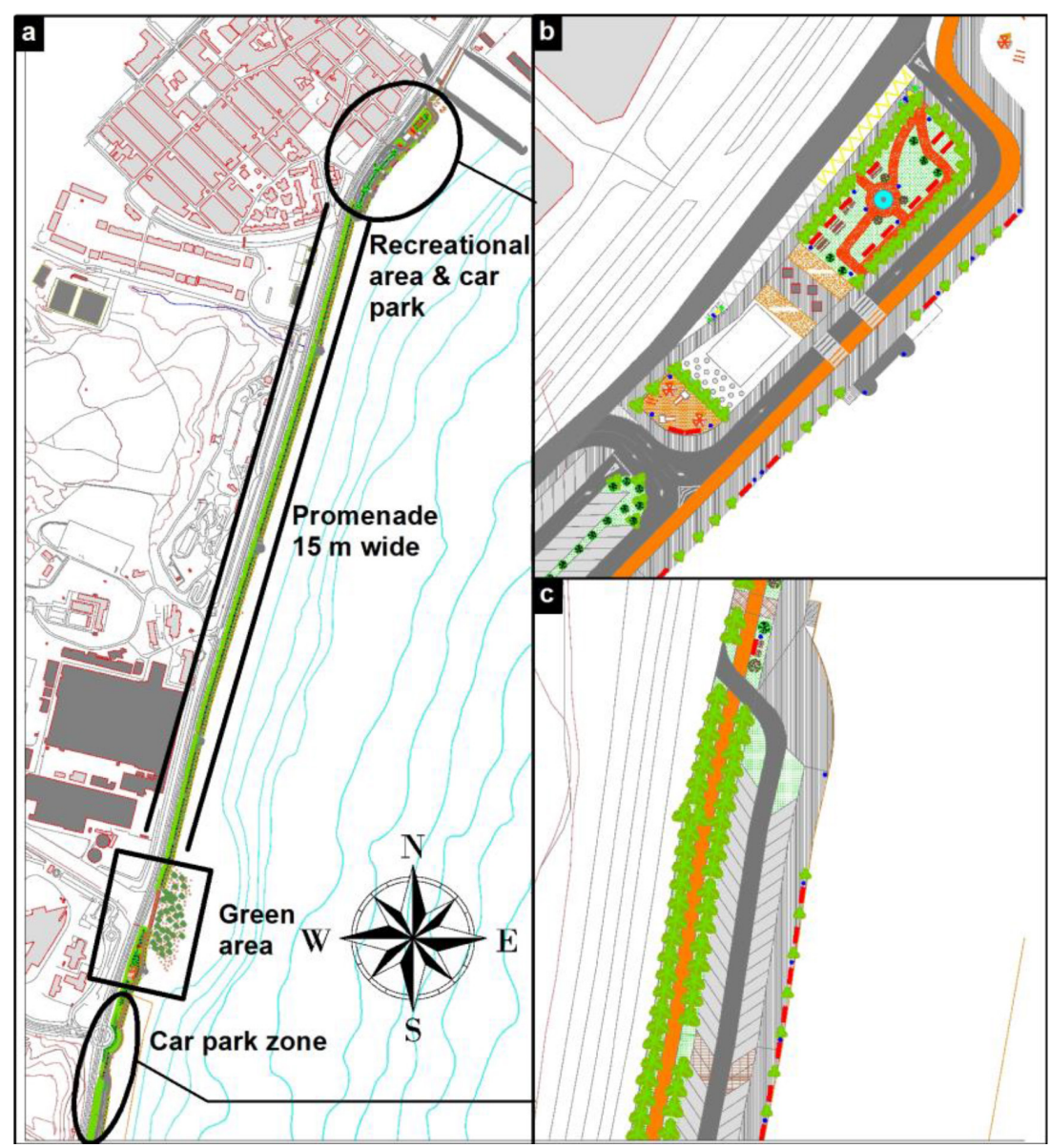

Figure 3: Solutions.

Regarding to the rehabilitation of the sea area, the proposed solution is to provide suitable areas for swimming and protecting the coastline, thereby creating areas of high tourist interest. The current breakwater protecting the entire coastline can be replaced with the construction of submerged breakwaters (Fig. 6). The approach would be to place nine breakwaters along the entire coastline until a total length of 92 meters each. They are placed on the bathymetric $-4.5 \mathrm{~m}$, about 230 meters from the actual coastline (Fig. 6). The spacing between them will be approximately 75 meters. The relationship between the length of the breakwaters and the spacing between them ensures the formation of small projections, plan form of the desired line of coast, as recommended by Pope and Dean 1986, collected in the Coastal Engineering Manual.

\section{CONCLUSIONS}

It is considered that in an area with a great location, its use should be maximized from different points of view: improving the natural conditions of the coast, providing places of public 


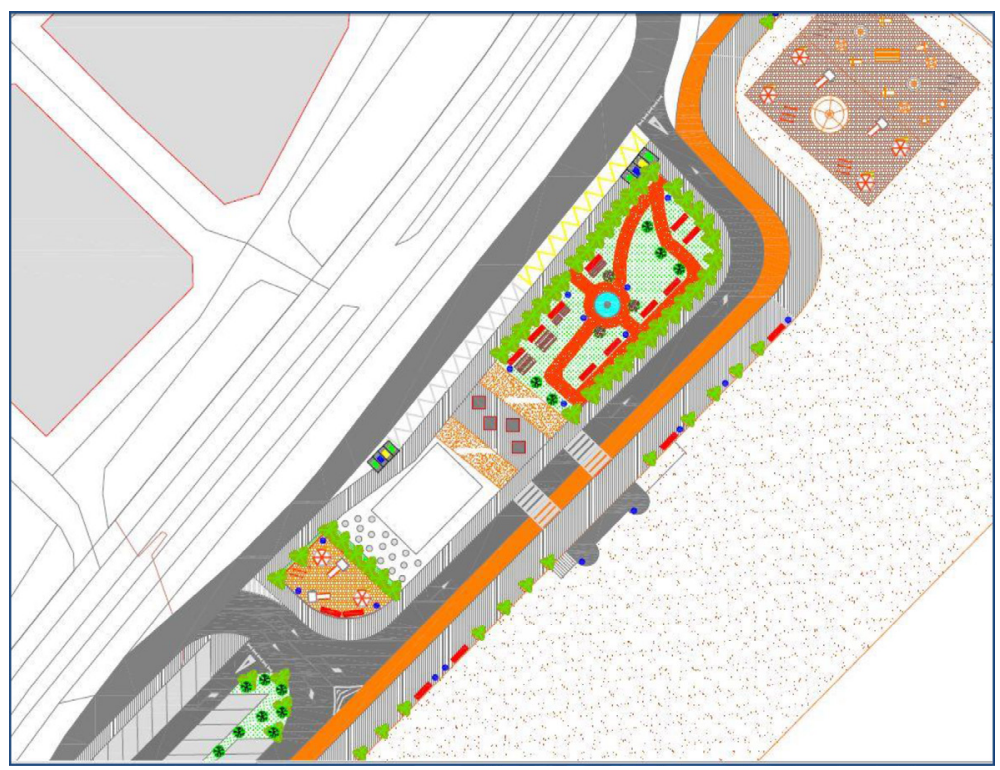

Figure 4: Parks and recreation areas.

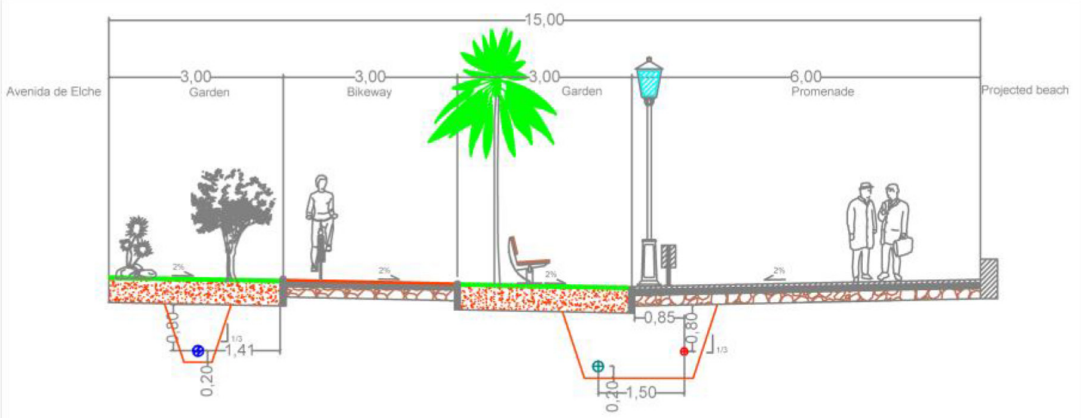

Figure 5: Main cross-section.

access encourage the important tourism sector in the area, solving the current urban development that generates conflicts and enhance inland areas with available residential sectors. So the southern part of Alicante meets all these conditions. Moreover, a great extension is undeveloped land. While there are various activities located in the area, giving it a greater complexity of applications, fragmentation of uses and the existence of spaces for the implementation of new activities allow greater restructuring of the whole territory. In this sense, the existence of the airport, the areas of tertiary and administrative activity, the chances of transformation of the some industrial sites, together with the expected residential growth in the area, make this area one of the biggest current challenges to consider.

It is also of interest, considering the city of Alicante as a city with a great tourist potential to be developed. Therefore, this study proposes to do it in a sustainable way. 


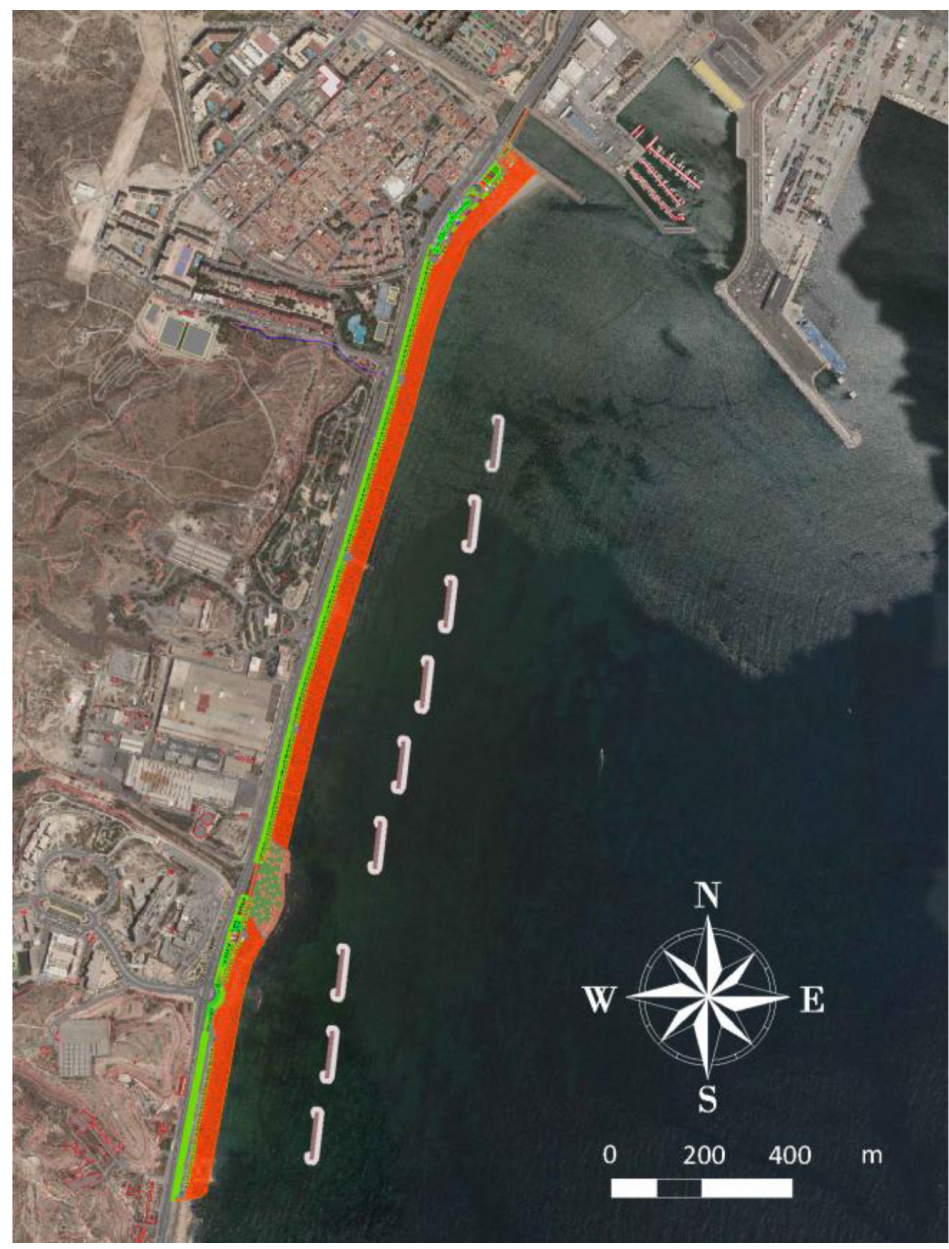

Figure 6: submerged breakwaters.

\section{REFERENCES}

[1] Hidalgo, A.R., Origen, desarrollo y problemática espacial de la ciudad de Alicante. Investigaciones Geográficas, (9), pp. 19-32, 1991.

[2] Martí Ciriquián, P. \& García González, M.C., Los procesos de dispersión y concentración territorial en Alicante y su entorno. 5th International Conference Virtual City and Territory, Barcelona, 2, 3 and 4 June 2009. eds, Centre de Política de Sòl i Valoracions, pp. 13-24, 2009.

[3] Ruiz, J.F., La transformación urbana como estrategia de cambio social: El caso de Bilbao. Confines, 21, pp. 155-159, 2015.

[4] ABC. ABC.es - Alicante, 2013, available at www.abc.es/local-alicante/20130915/abcifallecido-alicante-trencercanias-201309151256.html

[5] Información. Diario información, 2013, available at www.diarioinformacion.com/ sucesos/2013/09/16/pescador-fallece-alicante-arrollado-tren/1415579.html

[6] Mundo. Diario el Mundo, 2005 available at www.elmundo.es/elmundo/2005/12/05/sociedad/1133814350.html 